\title{
Antibiotic Resistance and Carriage Integron Classes in Clinical Isolates of Acinetobacter Baumannii from Isfahan Hospitals, Iran
}

\author{
Fahimeh Nourbakhsh, ${ }^{1,{ }^{*}}$ Majid Rajai, ${ }^{2}$ and Hassan Momtaz ${ }^{3}$ \\ ${ }^{1}$ Department of Pharmacology and Toxicology, Faculty of Pharmacy, Mashhad University of Medical Sciences, Mashhad, IR Iran \\ ${ }^{2}$ Expert of Al-Zahra Hospital Laboratories, Isfahan University of Medical Sciences, Isfahan, IR Iran \\ ${ }^{3}$ Department of Microbiology, Islamic Azad University of Shahrekord, Shahrekord, IR Iran \\ "Corresponding author: Fahimeh Nourbakhsh, Department of Pharmacology and Toxicology, Faculty of Pharmacy, Mashhad University of Medical Sciences, Mashhad, IR Iran. \\ E-mail: nourbakhshf951@mums.ac.ir
}

Received 2016 March 12; Revised 2016 June 13; Accepted 2017 January 09.

\begin{abstract}
Background: Acinetobacter baumannii is a significant nosocomial pathogen around the world, especially in the intensive care unit that most A. baumannii infections are caused by the outbreak strains.

Objectives: This study has been performed in Acinetobacter baumannii isolates, aimed to detect integron classes I, II, III and molecular typing of A. baumannii genes.

Methods: In this Cross-sectional study, Acinetobacter baumannii isolated from 150 patients in Isfahan hospitals then antibiotic resistance pattern was determined by disk diffusion method (Kirby Bauer). The presence of genes coding in antibiotic resistance and integrons class I, II, III were analyzed by using of M-PCR method. The data were analyzed by Chi-square, Fischer's test and SPSS statistical software version 16 .

Results: Antibiotic resistance pattern for Acinetobacter baumannii show that the high resistance was for ciprofloxacin with frequency of $98.3 \%$, ceftazidime with $89.4 \%$, and tetracycline with frequency of $87.3 \%$. The most sensitive antibiotics were chloramphenicol, and nitrofurantoin with frequency of 3.5\% and 3.2\% resistance. The detection of $d f r A 1(63.7 \%)$, sul1 (68.6\%), $\operatorname{aac}(3)-I V(54.4 \%), \operatorname{tet}(\mathrm{B})(22.4 \%)$, tet (A) (78.3\%), aadA1 (15.4\%), CITM (17. \%), vim (12.2\%), Qnr (17.1\%), blaSHV (19.8\%), sim (7.8\%), Oxa-24-like (13.2\%), Oxa-51-like (11.9\%), Oxa-58like (39.4\%), Oxa-23-like (12.6\%), imp (9.2\%), cmlA (19\%) and cat1 (8.6\%) were respectively reported too. Also in this study Frequency of integrons class 1, 2, 3 were (100\%), (28\%), (6.6\%) respectively.

Conclusions: High prevalence of integrons among Acinetobater baumannii isolated from Isfahan hospitals indicate the importance role of integron classes in multidrug resistance. Considering the increasing pattern of MDR infections is one of the important issues of treatment which can be effective strategy for curing.
\end{abstract}

Keywords: Antibiotic Resistance, Integron Classes, Acinetobacter baumannii

\section{Introduction}

Acinetobacter baumannii is a Gram-negative coccobacillus bacteria, aerobic and nonfermenting that belonging to the Moraxellaceae family these Species are opportunist pathogens with increasing relevance in both communityacquired and hospital-acquired, especially among patients in intensive care units and risk factor patient $[1,2]$. A. baumannii have been implicated in different nosocomial infections, including ventilator-associated pneumonia, endocarditis, meningitis, wounds, blood and infections of the skin, soft tissues, urinary tract infections, and those originating from other hospital environment [3]. A. baumannii can be isolated from numerous sources such as soil, water, animals, and humans, where ever presented in health care institutions or nosocomial infections or even in environmental surfaces, it will be difficult to control it $[4,5]$.

Antimicrobial resistance owing from enzymatic degradation, modification of targets, or bacterium in hospital environments are responsible for epidemics of A. baumannii in hospital-acquired species [6]. Current study show resistance to nearly all major classes of antibiotics, especially including broad-spectrum penicillin's, cephalosporin's, carbapenems, aminoglycosides, fluoroquinolones, chloramphenicol, and tetracycline's. Today there are global distributions of multidrug resistant (MDR) in clinical isolates all over the word [7].

Increasing of carbapenem-resistance and $\beta$ lactamases resistance in A. baumannii tend us to study genotypic and phenotypic resistance pattern in detected specimens which isolated from patients hospitalized in different sections of hospital $[8,9]$.

This study helps us to clarify different mode of $A$. baumannii antibiotic resistance pattern and its epidemiology in different hospitals. The current review was conducted to elucidate of antibiotic resistance in A. baumannii that detected from hospitalized patients in Isfahan Iran. 


\section{Methods}

\subsection{Bacterial Isolates}

A total of 150 isolates of A. baumannii was collected from clinical specimens from 3 major hospitals in Isfahan, Iran. Finally 150 clinical samples from individuals suffering from different types of infections were selected.

These isolates were characterized and confirmed in the laboratories of the corresponding hospitals through routine microbiological and biochemical tests such as IMVIC, urease, TSI, OF, MRVP, SIM, catalase, oxidase, and growth at $37^{\circ} \mathrm{C}$ and $42^{\circ} \mathrm{C}$. The confirmed samples were stored at $30 \%$ glycerol at $-70^{\circ} \mathrm{C}$.

A. baumannii including blood $(\mathrm{n}=38)$, wound $(\mathrm{n}=33)$, tracheal secretion $(n=10)$, meningitis $(n=6)$ and urinary infection ( $n=51$ ) which were collected from patients hospitalized in ICU, orthopedic and internal section. All samples were directly cultured in to $7 \%$ sheep blood agar (Merck, Darmstadt, Germany) and incubated aerobically at $37^{\circ} \mathrm{C}$ for 48 hours. After incubation, suspicious colonies were examined by using laboratory techniques appropriate for diagnosing A. baumannii species [10-12].

\subsection{Antibiotic Susceptibility Testing}

A. baumannii isolates was selected and the antibiotic resistance pattern was performed by a disk diffusion method on Mueller-Hinton agar.

A. baumannii isolates were tested for sensitivity to tetracycline (30 $\mu \mathrm{g})$, ceftazidime (30 $\mu \mathrm{g})$, ciprofloxacin (30 $\mu \mathrm{g})$, cotrimoxazole $(25 \mu \mathrm{g})$, tobramycin $(10 \mu \mathrm{g})$, Chloramphenicol (30 $\mu \mathrm{g})$, Norfloxacin (10 $\mu \mathrm{g})$, amikacin (30 $\mu \mathrm{g})$, gentamycin $(10 \mu \mathrm{g})$, Rifampin (5 $\mu \mathrm{g})$, cefalotin (30 $\mu \mathrm{g})$, Streptomycin $(10 \mu \mathrm{g})$, Trimethoprim $(5 \mu \mathrm{g})$, Levofloxacin $(5 \mu \mathrm{g})$, Imipenem $(10 \mu \mathrm{g})$, meropenem $(10 \mu \mathrm{g})$, Nitrofurantoin (300 $\mu \mathrm{g})$, azithromycin (15 $\mu \mathrm{g})$, erythromycin $(15 \mu \mathrm{g})$, by the Kirby-Bauer disk diffusion method. (MAST, Merseyside, England), according to clinical and laboratory standards institute (CLSI) 2011. A. baumannii ATCC 19606 was used as the positive control strain [13-15].

\subsection{Molecular Typing and DNA Extraction}

Detection of the main groups of genes which are effective in A. baumannii resistance were performed by using MPCR. The primers used are shown in Table 1. DNA extraction was carried out using the phenol chloroform method.

Primer pairs shown in Table 1 were used to detect antibiotic resistance genes, including aadA1 (streptomycin resistance), aac(3)-IV (gentamycin resistance), sul1 (sulfonamide resistance), blaSHV and CITM (beta-lactam resistance), cat1 and cmlA (chloramphenicol resistance), tet(A)

\begin{tabular}{|c|c|c|}
\hline Primers & Nucleotide Sequences $\left(5^{\prime}-3^{\prime}\right)$ & Expected Amplicon Size, bp \\
\hline \multirow{2}{*}{ 165-23S ribosomal DNA } & F-CATTATCACGGTAATTAGTG & \multirow{2}{*}{208} \\
\hline & R-AGAGCACTGTGCACTTAAG & \\
\hline \multirow{2}{*}{ aadA 1} & (F) TATCCAGCTAAGCGCGAACT & \multirow{2}{*}{447} \\
\hline & (R) ATTTGCCGACTACCTTGGTC & \\
\hline \multirow{2}{*}{$a a c(3)-I V$} & (F) CTTCAGGATGGCAAGTTGGT & \multirow{2}{*}{286} \\
\hline & (R) TCATCTCGTTCTCCGCTCAT & \\
\hline \multirow{2}{*}{ sult } & (F) TTCGGCATTCTGAATCTCAC & \multirow{2}{*}{822} \\
\hline & (R) ATGATCTAACCCTCGGTCTC & \\
\hline \multirow{2}{*}{ blasHV } & (F) TCGCCTGTGTATTATCTCCC & \multirow{2}{*}{768} \\
\hline & (R) CGCAGATAAATCACCACAATG & \\
\hline \multirow{2}{*}{ сттм } & (F) TGGCCAGAACTGACAGGCAAA & \multirow{2}{*}{462} \\
\hline & (R) TTTCTCCTGAACGTGGCTGGC & \\
\hline \multirow{2}{*}{ catr } & $\begin{array}{c}\text { (F) } \\
\text { AGTTGCTCATGGACCTATAACC }\end{array}$ & \multirow{2}{*}{547} \\
\hline & $\begin{array}{c}(\mathrm{R}) \\
\text { TTGTAATTCATTAAGCATTCTGCC }\end{array}$ & \\
\hline \multirow{2}{*}{ cmlA } & (F) CCGCCACGGTGTTGTTGTTATC & \multirow{2}{*}{698} \\
\hline & (R) CACCTTGCCTGCCCATCATTAG & \\
\hline \multirow{2}{*}{$\operatorname{tet}(A)$} & (F) GGTTCACTCGAACGACGTCA & \multirow{2}{*}{577} \\
\hline & (R) CTGTCCGACAAGTTGCATGA & \\
\hline \multirow{2}{*}{$\operatorname{tet}(B)$} & (F) CCTCAGCTTCTCAACGCGTG & \multirow{2}{*}{634} \\
\hline & (R) GCACCTTGCTGATGACTCTT & \\
\hline \multirow{2}{*}{ dfra1 } & (F)GGAGTGCCAAAGGTGAACAGC & \multirow{2}{*}{367} \\
\hline & $\begin{array}{l}\text { (R) } \\
\text { GAGGCGAAGTCTTGGGAAAAAC }\end{array}$ & \\
\hline \multirow{2}{*}{ Qnr } & $\begin{array}{l}\text { (F) } \\
\text { GGGTATGGATATTATTGATAAAG }\end{array}$ & \multirow{2}{*}{670} \\
\hline & (R) CTAATCCGGCAGCACTATTTA & \\
\hline \multirow{2}{*}{$\operatorname{Imp}$} & (F) GAATAGAATGGTTAACTCTC & \\
\hline & (R) CCAAACCACTAGGTTATC & \\
\hline Vis & (F) GTTTGGTCGCATATCGCAAC & \\
\hline & (R) AATGCGCAGCACCAGGATAG & 382 \\
\hline $\operatorname{sim}$ & (F) GTACAAGGGATTCGGCATCG & 569 \\
\hline & (R) GTACAAGGGATTCGGCATCG & \\
\hline 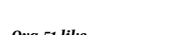 & (F) TAATGCTTTGATCGGCCTTG & (2) \\
\hline & (R) TGGATTGCACTTCATCTTGG & \\
\hline $0 \times a=23$ like & (F) GATCGGATTGGAGAACCAGA & -50 \\
\hline oxacz-zine & (R) ATTTCTGACCGCATTTCCAT & \\
\hline Oro & (F) GGTTAGTTGGCCCCCTTAAA & 206 \\
\hline & (R) AGTTGAGCGAAAAGGGGATT & \\
\hline Ovo-soljike & (F) AAGTATTGGGGCTTGTGCTG & \\
\hline & (R) СССCTCTGCGCTCTACATAC & 年 \\
\hline Intr & F: CAG TGG ACA TAA GCC TGT TC & 160 \\
\hline mitu & R: CCC GAC GCA TAG ACT GTA & \\
\hline IntII & F: TTG CGA GTA TCC ATA ACC TG & 288 \\
\hline & R: TTA CCT GCA CTG GAT TAA GC & \\
\hline Intw & $\begin{array}{c}\text { F: GCC TCC GGC AGC GAC TTT } \\
\text { CAG }\end{array}$ & 1041 \\
\hline & $\begin{array}{l}\text { R:ACG GAT CTG CCAAAC CTG } \\
\text { ACT }\end{array}$ & \\
\hline
\end{tabular}

and tet $(B)$ (tetracycline resistance), $d f r A 1$ (trimethoprim resistance), qnr (quinolone resistance), imp, vim, and sim (carbenicillin resistance), and Oxa-23-like, Oxa-24-like, Oxa-51- 
like, and Oxa-58-like (oxacillin resistance). Genomic DNAs of A. baumannii isolates were extracted using Genomic DNA Purification Kit (fermentas Lithuania) and implemented as a template DNA in PCR amplification of the intended fragments. The PCR programs were set according to the size of the fragments as follows:

A multiplex PCR containing $50 \mu \mathrm{L}$ of ingredients $(5 \mu \mathrm{L}$ of $10 X$ PCR buffer, $2 \mathrm{mmol}$ of $\mathrm{MgCl}_{2}, 150 \mu \mathrm{mol}$ of dNTPs mix, $0.5 \mu \mathrm{mol}$ of $\mathrm{F}$ and R primer pairs (for each gene), 1.5 unit of Taq DNA polymerase, and $2 \mu \mathrm{L}$ of each DNA sample) was used to detect aadA1, aac (3)-IV, sul1, blaSHV, CITM, cat1, cmlA, tet (a), tet (B), dfrA1, and qnr. The thermal program was a cycle of $94^{\circ} \mathrm{C}$ for 6 minutes, 33 repetitive cycles of $95^{\circ} \mathrm{C}$ for 70 seconds, $55^{\circ} \mathrm{C}$ for 65 seconds, and $72^{\circ} \mathrm{C}$ for 90 seconds, and a final cycle of $72^{\circ} \mathrm{C}$ for 8 minutes [15-18]. Strains of $E$. coli O157:K88ac:H19, CAPM 5933 and E. coli O159:H20, CAPM 6006 were used as the positive controls. The amplification of imp, vim, and sim genes was carried out in a multiplex PCR in a volume of $50 \mu \mathrm{L}$ containing $5 \mu \mathrm{L}$ of $10 \mathrm{X}$ PCR buffer, $1.5 \mathrm{mmol}$ of $\mathrm{MgCl}_{2}, 100 \mu \mathrm{mol}$ of dNTPs mix, $1.0 \mu \mathrm{mol}$ of forward and reveres primer pairs (for each gene), 1.0 unit of Taq DNA polymerase, and $2.5 \mu \mathrm{L}$ of each DNA. The program was set to a cycle of $95^{\circ} \mathrm{C}$ for 4 minutes, 30 repetitive cycles of $94^{\circ} \mathrm{C}$ for 45 seconds, $58^{\circ} \mathrm{C}$ for 60 seconds, and $72^{\circ} \mathrm{C}$ for 40 seconds, and a final cycle of $72^{\circ} \mathrm{C}$ for 5 minutes [19]. Oxacillin resistance genes (Oxa-23-like, Oxa-24-like, Oxa51-like, Oxa-58-like) were detected in a $50 \mu \mathrm{L}$ multiplex PCR with $5 \mu \mathrm{L}$ of $10 X$ PCR buffer, $2.5 \mathrm{mmol}$ of $\mathrm{MgCl}_{2}, 200 \mu \mathrm{mol}$ of dNTPs mix, $0.5 \mu \mathrm{mol}$ of forward and reveres primer pairs (for each gene), 1.5 unit of Taq DNA polymerase, and 2.0 $\mu \mathrm{L}$ of each DNA of each isolate. The program included a cycle of $94^{\circ} \mathrm{C}$ for 5 minutes, 32 repetitive cycles of $95^{\circ} \mathrm{C}$ for 50 seconds, $60{ }^{\circ} \mathrm{C}$ for 60 seconds, and $72^{\circ} \mathrm{C}$ for 70 seconds, as well as a final cycle of $72^{\circ} \mathrm{C}$ for 10 minutes [16-20].

50 microliters of M-PCR products were resolved on a $1.5 \%$ agarose gel containing $0.5 \mathrm{mg} / \mathrm{mL}$ of ethidium bromide in Tris-borate-EDTA buffer at $90 \mathrm{~V}$ for 1 hour. Finally the products were examined with ultraviolet illumination [20].

\subsection{Analyzing the Presence of Integrons}

Classes 1, 2, and 3 integrons were detected using the primers shown in Table 1 in the multiplex PCR. The reaction volume was set to $25 \mu \mathrm{L}$ containing $2.5 \mu \mathrm{L}$ of 10X PCR buffer, $1.5 \mathrm{mmol}$ of $\mathrm{MgCl}_{2}, 200 \mu \mathrm{mol}$ of dNTPs mix, $0.5 \mu \mathrm{mol}$ of forward and reveres primer pairs, 1.0 unit of Taq DNA polymerase, and $2.5 \mu \mathrm{L}$ of each DNA sample. Thermal program was set to a cycle of $94^{\circ} \mathrm{C}$ for 6 minutes, 35 repetitive cycles of $94^{\circ} \mathrm{C}$ for 1 minutes, $56^{\circ} \mathrm{C}$ for 1 minutes, and $72^{\circ} \mathrm{C}$ for 45 seconds, as well as a final cycle of $72^{\circ} \mathrm{C}$ for 6 minutes. Since the positive control sample was not used in regard with detection of some genes, to confirm or reject the PCR results, the PCR products of the primary positive samples were purified using a PCR product purification kit (Roche Applied Science, Germany) and sent to the Macrogen Co. (South Korea) for sequencing. The PCR amplifications were carried out in an Eppendorf, Mastercycler® 5330 (EppendorfNetheler-Hinz GmbH, Hamburg Germany). The amplified fragments were visualized on ethidium bromide containing $1.5 \%$ of agarose gels, in which $15 \mu \mathrm{L}$ of each product was loaded, in addition to 100 bp DNA marker (fermentasLithuania), on a UV transluminator (UV itech, England) after electrophoresis at $90 \mathrm{~V}$ for approximately 45 minutes.

24-like, Oxa-51-like, and Oxa-58-like (oxacillin resistance). Genomic DNAs of A. baumannii isolates were extracted using Genomic DNA Purification Kit (fermentas Lithuania) and implemented as a template DNA in PCR amplification of the intended fragments. The PCR programs were set according to the size of the fragments as follows:

A multiplex PCR containing $50 \mu \mathrm{L}$ of ingredients $(5 \mu \mathrm{L}$ of $10 X$ PCR buffer, $2 \mathrm{mmol}$ of $\mathrm{MgCl}_{2}, 150 \mu \mathrm{mol}$ of dNTPs mix, $0.5 \mu \mathrm{mol}$ of $\mathrm{F}$ and $\mathrm{R}$ primer pairs (for each gene), 1.5 unit of Taq DNA polymerase, and $2 \mu \mathrm{L}$ of each DNA sample) was used to detect aadA1, aac (3)-IV, sul1, blaSHV, CITM, cat1, cmlA, tet (a), tet (B), dfrA1, and $q n r$. The thermal program was a cycle of $94^{\circ} \mathrm{C}$ for 6 minutes, 33 repetitive cycles of $95^{\circ} \mathrm{C}$ for 70 seconds, $55^{\circ} \mathrm{C}$ for 65 seconds, and $72^{\circ} \mathrm{C}$ for 90 seconds, and a final cycle of $72^{\circ} \mathrm{C}$ for 8 minutes [15-18]. Strains of $E$. coli O157:K88ac:H19, CAPM 5933 and E. coli O159:H20, CAPM 6006 were used as the positive controls. The amplification of imp, vim, and sim genes was carried out in a multiplex PCR in a volume of $50 \mu \mathrm{L}$ containing $5 \mu \mathrm{L}$ of 10X PCR buffer, $1.5 \mathrm{mmol}$ of $\mathrm{MgCl}_{2}, 100 \mu \mathrm{mol}$ of dNTPs mix, $1.0 \mu \mathrm{mol}$ of forward and reveres primer pairs (for each gene), 1.0 unit of Taq DNA polymerase, and $2.5 \mu \mathrm{L}$ of each DNA. The program was set to a cycle of $95^{\circ} \mathrm{C}$ for 4 minutes, 30 repetitive cycles of $94^{\circ} \mathrm{C}$ for 45 seconds, $58^{\circ} \mathrm{C}$ for 60 seconds, and $72^{\circ} \mathrm{C}$ for 40 seconds, and a final cycle of $72^{\circ} \mathrm{C}$ for 5 minutes [19]. Oxacillin resistance genes (Oxa-23-like, Oxa-24-like, Oxa51-like, Oxa-58-like) were detected in a $50 \mu \mathrm{L}$ multiplex PCR with $5 \mu \mathrm{L}$ of $10 X$ PCR buffer, $2.5 \mathrm{mmol}$ of $\mathrm{MgCl}_{2}, 200 \mu \mathrm{mol}$ of dNTPs mix, $0.5 \mu \mathrm{mol}$ of forward and reveres primer pairs (for each gene), 1.5 unit of ribosomal DNA) through simple disc diffusion method. All the studied isolates demonstrated the multidrug resistance (MDR).

\subsection{Statistical Analysis}

The collected data were analyzed by SPSS statistical software (ver.16) using Chi-square and Fischer's exact statistical tests at the confidence level of 95 percent. 


\section{Results}

During this study, 220 samples of Acinetobacter were collected from different patients in internal section, orthopedic and ICU. One hundred and fifty samples of isolate were identified as A. baumannii (68.8\%), 50 samples were Acinetobacter Lwoffi (27.7\%) and 20 samples (9.09\%) were identified as other Acinetobacter species. Among of isolated A. baumannii strains, all samples (100\%) were multidrugresistant. Results of this study showed that 79 samples of A. baumannii (52.6\%) were resistant to three or more than three antibiotics and 97 samples (64.6\%) showed resistance to more than two antibiotics. Also, none of resistant strains were showed complete resistance to all antibiotics. According to antibiotic resistance pattern, it was mentioned that, approximately $98.3 \%$ of samples were resistant to ciprofloxacin, $89.4 \%$ of isolates were resistance to ceftazidime and there were $87.3 \%$ resistance to tetracycline. Other antimicrobial resistance profiles of A. baumannii is shown in Table 2.

Table 2. Antibiotic Resistance Pattern in A. baumannii Isolates

\begin{tabular}{|c|c|c|c|}
\hline Antibiotic & $\begin{array}{c}\text { Sensitive } \\
\text { Percent }\end{array}$ & $\begin{array}{c}\text { Intermediate } \\
\text { Percent }\end{array}$ & $\begin{array}{c}\text { Resistance } \\
\text { Percent }\end{array}$ \\
\hline Tetracycline & 87.3 & 10.8 & 1.9 \\
\hline Ceftazidime & 89.4 & 5.2 & 5.4 \\
\hline Ciprofloxacin & 98.3 & 1.7 & 0 \\
\hline Cotrimoxazole & 65 & 25.1 & 9.9 \\
\hline Tobramycin & 53 & 35.4 & 11.6 \\
\hline Chloramphenico & 3.5 & 11.5 & 85 \\
\hline Norfloxacin & 78 & 12.5 & 9.5 \\
\hline Amikacin & 55.7 & 30.3 & 14 \\
\hline Gentamycin & 79.5 & 18.3 & 2.2 \\
\hline Rifampin & 45.8 & 40.8 & 13.4 \\
\hline Cefalotin & 56.1 & 27.3 & 16.6 \\
\hline Streptomycin & 34.3 & 7 & 58.7 \\
\hline Trimethoprim & 73 & 13.6 & 13.4 \\
\hline Levofloxacin & 55 & 20.5 & 24.5 \\
\hline Imipenem & 43 & 38.8 & 18.2 \\
\hline Meropenem & 66.5 & 29.4 & 4.1 \\
\hline Nitrofurantoin & 3.2 & 13.5 & 83.3 \\
\hline Azithromycin & 74 & 14.5 & 11.5 \\
\hline Erythromycin & 65 & 17.9 & 17.1 \\
\hline
\end{tabular}

Molecular typing of genes that related to A. baumannii antibiotic resistance pattern show the frequency of genes as dfrA1 (63.7\%), sul1 (68.6\%), aac(3)-IV (54.4\%), tet(B) (22.4\%),
tet(A) (78.3\%), aadA1 (15.4\%), CITM (17. \%), vim (12.2\%), Qnr (17.1\%), blaSHV (19.8\%), sim (7.8\%), Oxa-24-like (13.2\%), Oxa-51like (11.9\%), Oxa-58-like (39.4\%), Oxa-23-like (12.6\%), imp (9.2\%), cmlA (19\%) and cat1 (8.6\%) respectively. Frequency of integrons class I, II, III was (100\%), (28\%), (6.6\%) respectively. There were a significant relationship between integron I gene and detected specimens. All of the specimens were contains integron class I. Frequency of other integron classes and its relationship with different groups of specimens are show in Table 3.

Table 3. Frequency of Integron Classes with Different Groups of Specimens

\begin{tabular}{lccc}
\hline Frequency Sample Type & Integron I & Integron II & Integron III \\
\hline 38/Blood & 38 & 9 & 1 \\
33/Wound & 33 & 10 & 2 \\
\hline 51/UTI & 51 & 16 & 1 \\
6/meningitis & 6 & 2 & 1 \\
22/T. secretion & 22 & 5 & 5 \\
Total & 150 & 42 & 10 \\
\hline
\end{tabular}

A. baumannii isolates which detected from different Patients in Prevalence of age show that the most frequent age range of the patients were between 61 - 70 age (57.9\%) who were hospitalized in different section of hospitals. Also $69 \%$ of patients were women in this study.

In current study most of the integron class I and integron classes II were found among multidrug resistant $A$. baumannii strains. The results of our study were in concordance with similar studies around the world. Due to increased drug resistance, wider search and further study is necessary and can be useful to control hospital infections [21]. Gel electrophoresis of samples are show in Figures 1 3.

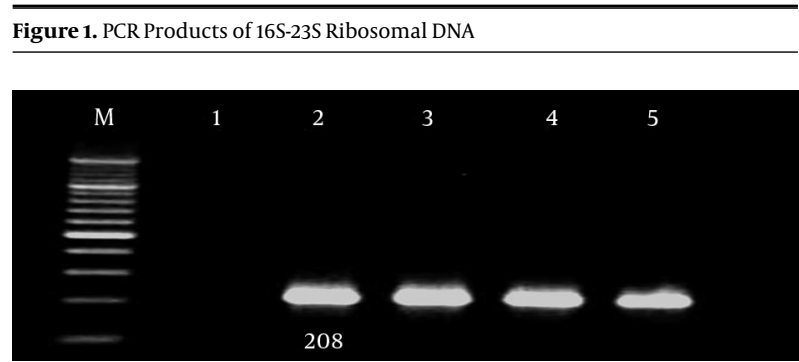

M, marker; 1, negative; 2 - 5, positive 
Figure 2. PCR Products of Genes

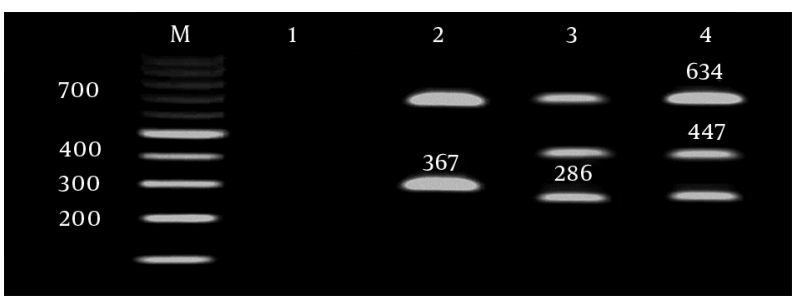

M, marker; 1, negative; 286, aac (3)-IV; 367, dfrA1; 447, aadA1; 634, tetB.

Figure 3. PCR Products of Genes

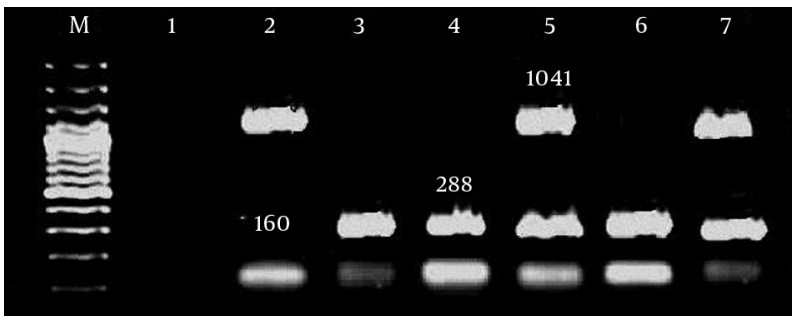

M, marker; 1, 2 - 7, IntI; 288, IntII; 1041, IntIII.

\section{Discussion}

Molecular typing of genes that related to A. baumannii antibiotic resistance pattern show the frequency of genes as dfrA1 (63.7\%), sul1 (68.6\%), aac(3)-IV (54.4\%), tet(B) (22.4\%), tet(A) (78.3\%), aadA1 (15.4\%), CITM (17. \%), vim (12.2\%), Qnr (17.1\%), blaSHV (19.8\%), sim (7.8\%), Oxa-24-like (13.2\%), Oxa-51-like (11.9\%), Oxa-58-like (39.4\%), Oxa-23-like (12.6\%), imp (9.2\%), cmlA (19\%) and cat1 (8.6\%) respectively. Frequency of integrons class I, II, III was (100\%), (28\%), (6.6\%) respectively. There was a significant relationship between integron I gene and detected specimens. All of the specimens were contains integron class I. Frequency of other integron classes and its relationship with different groups of specimens were show in Table 3.

Different species of Acinetobacter have strong tendency to become resistant to antibiotics and are inherently resistant to some broad antibiotics, and on the other hand have a great ability to gain new mechanisms of resistance. Plasmids, transposons and integrons are important factors in the acquisition and transfer the mechanisms of antibiotic resistance [22].

Today, the spread of antibiotic resistance through integron structures with multiple antibiotic resistance has become a serious problem in treatment of infections caused by Acinetobacter baumannii. Due to the spread of antibiotic resistance in Acinetobacter baumannii, and since the city had not done a comprehensive study on antibiotic resistance of these bacteria, this study was conducted to show pattern of antibiotic resistance, genetic pattern of antibiotic resistance and tracking Integrons classes. All isolates examined in this study were MDR [23].

The highest rate of drug resistance related to tetracycline (87.3\%), ciprofloxacin (98.3\%), and ceftazidime (89.4). Similar studies have been conducted in different regions of Iran too. In a similar study conducted by Momtaz et al. (2015) in two large hospitals in Tehran, almost similar pattern was observed that $90.90 \%$ of Acinetobacter baumannii isolated from human infection were resistance to tetracycline, $61.98 \%$ to trimethoprim, 51.23\% were resistance to cotrimoxazole and between $9.91 \%$ to $31.40 \%$ of isolates were resistant to aminoglycoside compounds [24].

In a study done by Shakibaii on 50 isolates of A. baumannii which detected from the intensive care unit in Kerman hospitals, the antibiotic-resistant pattern show 73.3\% resistance to imipenem, 66\% to ciprofloxacin, $93.3 \%$ to piperacillin-tazobactam, 53.3\% to amikacin, $93.3 \%$ to Cefepime and $100 \%$ reported to piperacillin [25].

In a study conducted by Aliakbarzade et al. (2014) in Tabriz hospitals, antibiotic resistance pattern of Acinetobacter baumannii isolated from patients were at a rate of $94 \%$ to kanamycin, $86 \%$ to gentamicin, $81 \%$ were resistant to amikacin and $63 \%$ were resistant to tobramycin. Different antibiotic resistance in various studies can be related to clinical sample types, or geographic region of the test [26].

Distribution genes encoding resistance to antibiotics was one of the goals of this study. The presence of this genes coding in antibiotic resistance was show in this 150 isolates. Molecular typing of genes that related to A. baumannii antibiotic resistance pattern show the frequency of genes as dfrA1 (63.7\%), sul1 (68.6\%), aac(3)-IV (54.4\%), tet(B) (22.4\%), tet(A) (78.3\%), aadA1 (15.4\%), CITM (17. \%), vim (12.2\%), Qnr (17.1\%), blaSHV (19.8\%), sim (7.8\%), Oxa-24-like (13.2\%), Oxa-51-like (11.9\%), Oxa-58-like (39.4\%), Oxa-23-like (12.6\%), imp (9.2\%), cmlA (19\%) and cat1 (8.6\%) respectively and integrons class I, II, III was (100\%), (28\%),(6.6\%)respectively. Compared with this study, Huang et al. (2008) in China, reported distribution of $\beta$-lactamase genes that were evaluated in 21 isolates of A. baumannii. In this study all of the isolates contain $b l a_{O X A-51-L i k e}$ and just 8 strains contains bla $a_{\text {OXA-23-Like }}$ gene [27].

Another study by Arezzo in Italy (2011) show that 93.8\% of 114 isolates were resistance to imipenem and $71.1 \%$ of isolates contains bla $a_{\text {OXA-23-Like }}$ genes and $22.8 \%$ of isolates contains $b l a_{\text {OXA-58-Like, }}$ Compared with our study they didn't detect Oxa-24-like, Oxa-51-like, vim, sim and imp in their isolates [28].

Frequency of integrons class I, II, III in our study was 
(100\%), (28\%), (6.6\%) respectively. There was a significant relationship between integron I gene and detected specimens. All of the specimens were contains integron class I.

Unlike these results in the study of Mirnejad et al. (2012) $82 \%$ of Acinetobacter baumannii isolated from hospitals in Tehran, carried Integrons Class II. There was a significant correlation between integrons and antibiotics resistance pattern to Cefepime, aztreonam, amikacin, ciprofloxacin, norfloxacin, ofloxacin and ceftazidime [29].

Also in a survey conducted by Mohammadi et al. presence of integrase gene I, II and III in XDR of Acinetobacter baumannii which detected from patients in Hamedan hospitals, was $97 \%, 31 \%$ and $0 \%$ respectively [30]. In a study in Taiwan, $72 \%$ of Acinetobacter baumannii just contains integrase gene class I [31].

In Koczura reviews (2014) in Poland only 63.5\% of Acinetobacter baumannii contains integron class I. Similar to this study in Turkey (2014) only 33\% of the isolates of the bacteria carry Integrons class I, and class II [32].

Because of the differences in the prevalence of class I integrons in two recent studies with this study and also similar studies in Iran, so it can probably relate to the verities of geographical area , the proper use and control of antibiotics in out of Iran [33].

\section{Acknowledgments}

Corresponding author expresses her gratitude to the esteemed professor: Dr Hassan momtaz for his Scientific and Valuable advice. This article was supported by Islamic Azad University of shahrekord, Iran and with personal fee.

\section{Footnotes}

Authors' Contribution: Fahimeh Nourbakhsh provided conception and design of the study and revised the article. Majid Rajai and Fahimeh Nourbakhsh participated in data collection and drafting the manuscript, also the data analysis and interpretation performed by DR. Hassan Momtaz.

Funding/Support: This paper had been supported by Islamic Azad University of Shahrekord, Iran with personal fee.

\section{References}

1. Mengeloglu FZ, Copur Cicek A, Kocoglu E, Sandalli C, Budak EE, Ozgumus OB. [Carriage of class 1 and 2 integrons in Acinetobacter baumannii and Pseudomonas aeruginosa isolated from clinical specimens and a novel gene cassette array: blaOXA-11-cmlA7]. Mikrobiyol Bul. 2014;48(1):48-58. [PubMed: 24506715].

2. Japoni S, Japoni A, Farshad S, Ali AA, Jamalidoust M. Association between existence of integrons and multi-drug resistance in Acinetobacter isolated from patients in southern Iran. Pol J Microbiol. 2011;60(2):163-8. [PubMed: 21905635].
3. Peymani A, Farajnia S, Nahaei MR, Sohrabi N, Abbasi L, Ansarin K, et al. Prevalence of class 1 integron among multidrug-resistant Acinetobacter baumannii in Tabriz, northwest of Iran. Pol J Microbiol. 2012;61(1):57-60. [PubMed: 22708347].

4. Farahani Kheltabadi R, Moniri R, Shajari GR, Shirazi MHN, Musavi SGA, Ghasemi A, et al. Antimicrobial Susceptibility patterns and the distribution of resistance genes among Acinetobacter species isolated from patients in shahid Beheshti hospital, Kashan. Feyz J Kashan Univ Med Sci. 2009;12(4).

5. Azhari F, Farajnia S, Rahnema M. Investigation of prevalence of esbl types veb-1 and per- 2 genes and int- 1 in acinetobacter bumanii strains isolated from patients of imam reza hospital intabriz. Q J Biol Sci. 2010;4(11):1-10.

6. Manchanda V, Sanchaita S, Singh N. Multidrug resistant acinetobacter. J Glob Infect Dis. 2010;2(3):291-304. doi: 10.4103/0974-777X.68538. [PubMed: 20927292].

7. Stokes HW, Gillings MR. Gene flow, mobile genetic elements and the recruitment of antibiotic resistance genes into Gram-negative pathogens. FEMS Microbiol Rev. 2011;35(5):790-819. doi: 10.1111/j.15746976.2011.00273.x. [PubMed: 21517914].

8. Adams MD, Goglin K, Molyneaux N, Hujer KM, Lavender H, Jamison JJ, et al. Comparative genome sequence analysis of multidrugresistant Acinetobacter baumannii. J Bacteriol. 2008;190(24):805364. doi: 10.1128/JB.00834-08. [PubMed: 18931120].

9. Fishbain J, Peleg AY. Treatment of Acinetobacter infections. Clin Infect Dis. 2010;51(1):79-84. doi: 10.1086/653120. [PubMed: 20504234].

10. Ploy MC, Denis F, Courvalin P, Lambert T. Molecular characterization of integrons in Acinetobacter baumannii: description of a hybrid class 2 integron. Antimicrob Agents Chemother. 2000;44(10):2684-8. [PubMed: 10991844].

11. Koeleman JG, Stoof J, Van Der Bijl MW, Vandenbroucke-Grauls CM, Savelkoul PH. Identification of epidemic strains of Acinetobacter baumannii by integrase gene PCR. J Clin Microbiol. 2001;39(1):8-13. doi: 10.1128/JCM.39.1.8-13.2001. [PubMed: 11136740].

12. Woodford N, Ellington MJ, Coelho JM, Turton JF, Ward ME, Brown S, et al. Multiplex PCR for genes encoding prevalent OXA carbapenemases in Acinetobacter spp. Int J Antimicrob Agents. 2006;27(4):351-3. doi: 10.1016/j.ijantimicag.2006.01.004. [PubMed: 16564159].

13. Mendes RE, Kiyota KA, Monteiro J, Castanheira M, Andrade SS, Gales AC, et al. Rapid detection and identification of metallobeta-lactamase-encoding genes by multiplex real-time PCR assay and melt curve analysis. J Clin Microbiol. 2007;45(2):544-7. doi: 10.1128/JCM.01728-06. [PubMed: 17093019].

14. Randall LP, Cooles SW, Osborn MK, Piddock LJ, Woodward MJ. Antibiotic resistance genes, integrons and multiple antibiotic resistance in thirty-five serotypes of Salmonella enterica isolated from humans and animals in the UK. JAntimicrob Chemother. 2004;53(2):208-16. doi: 10.1093/jac/dkh070. [PubMed: 14729766].

15. Clinical and Laboratory Standards Institute . Performance standards for antimicrobial disk susceptibility testing; 20th informational supplement. CLSI/NCCLS M100-S20. Wayne: Clinical and Laboratory Standards Institute; 2010.

16. Mammeri H, Van De Loo M, Poirel L, Martinez-Martinez L, Nordmann P. Emergence of plasmid-mediated quinolone resistance in Escherichia coli in Europe. Antimicrob Agents Chemother. 2005;49(1):71-6. doi: 10.1128/AAC.49.1.71-76.2005. [PubMed: 15616277].

17. Toro CS, Farfan M, Contreras I, Flores O, Navarro N, Mora GC, et al. Genetic analysis of antibiotic-resistance determinants in multidrugresistant Shigella strains isolated from Chilean children. Epidemiol Infect. 2005;133(1):81-6. [PubMed: 15724714].

18. Van TT, Chin J, Chapman T, Tran LT, Coloe PJ. Safety of raw meat and shellfish in Vietnam: an analysis of Escherichia coli isolations for antibiotic resistance and virulence genes. Int J Food Microbiol. 2008;124(3):217-23. doi: 10.1016/j.ijfoodmicro.2008.03.029. [PubMed: 18457892]. 
19. Hujer KM, Hujer AM, Hulten EA, Bajaksouzian S, Adams JM, Donskey $\mathrm{CJ}$, et al. Analysis of antibiotic resistance genes in multidrug-resistant Acinetobacter sp. isolates from military and civilian patients treated at the Walter Reed Army Medical Center. Antimicrob Agents Chemother. 2006;50(12):4114-23. doi: 10.1128/AAC.00778-06. [PubMed: 17000742].

20. Chiang MC, Kuo SC, Chen YC, Lee YT, Chen TL, Fung CP. Polymerase chain reaction assay for the detection of Acinetobacter baumannii in endotracheal aspirates from patients in the intensive care unit. J Microbiol Immunol Infect. 2011;44(2):106-10. doi: 10.1016/j.jmii.2010.04.003. [PubMed: 21439512].

21. Rowe-Magnus DA, Mazel D. The role of integrons in antibiotic resistance gene capture. Int J Med Microbiol. 2002;292(2):115-25. doi: 10.1078/1438-4221-00197. [PubMed: 12195734].

22. Xu Z, Li L, Shirtliff ME, Alam MJ, Yamasaki S, Shi L. Occurrence and characteristics of class 1 and 2 integrons in Pseudomonas aeruginosa isolates from patients in southern China.J Clin Microbiol. 2009;47(1):2304. doi:10.1128/JCM.02027-08. [PubMed:19020065].

23. Irfan S, Turton JF, Mehraj J, Siddiqui SZ, Haider S, Zafar A, et al. Molecular and epidemiological characterisation of clinical isolates of carbapenem-resistant Acinetobacter baumannii from public and private sector intensive care units in Karachi, Pakistan. J Hosp Infect. 2011;78(2):143-8. doi: 10.1016/j.jhin.2011.01.029. [PubMed: 21459477].

24. Momtaz H, Khamesipour F, Tavakol M, Awosile B. Determination of Antimicrobial Resistance and Resistant Genes in Acinetobacter baumannii from Human Clinical Samples. West Indian Med J. 2015 doi: 10.7727/wimj.2014.337. [PubMed: 27399055].

25. Shakibaie MR, Adeli S, Salehi MH. Antibiotic resistance patterns and extended-spectrum beta-lactamase production among Acinetobacter spp. isolated from an intensive care Unit of a hospital in Kerman, Iran. Antimicrob Resist Infect Control. 2012;1(1):1. doi:10.1186/2047-29941-1. [PubMed: 22958725].

26. Aliakbarzade K, Farajnia S, Karimi Nik A, Zarei F, Tanomand A. Prevalence of Aminoglycoside Resistance Genes in Acinetobacter baumannii Isolates. Jundishapur J Microbiol. 2014;7(10):e11924. doi: 10.5812/jjm.11924. [PubMed: 25632323].

27. Huang L, Sun L, Xu G, Xia T. Differential susceptibility to carbapenems due to the AdeABC efflux pump among nosocomial outbreak isolates of Acinetobacter baumannii in a Chinese hospital. Diagn Microbiol Infect Dis. 2008;62(3):326-32. doi: 10.1016/j.diagmicrobio.2008.06.008. [PubMed: 18687557].

28. D'Arezzo S, Principe L, Capone A, Petrosillo N, Petrucca A, Visca P. Changing carbapenemase gene pattern in an epidemic multidrugresistant Acinetobacter baumannii lineage causing multiple outbreaks in central Italy. J Antimicrob Chemother. 2011;66(1):54-61. doi: 10.1093/jac/dkq407. [PubMed: 21088019].

29. Mirnejad R, Mostofi S, Masjedian F. Antibiotic resistance and carriage class 1 and 2 integrons in clinical isolates of Acinetobacter baumannii from Tehran, Iran. Asian Pac J Trop Biomed. 2013;3(2):140-5. doi: 10.1016/S2221-1691(13)60038-6. [PubMed: 23593593].

30. Moammadi F, Arabestani MR, Safari M, Roshanaii G, Alikhani MY. Prevalence of class1, 2 and 3 integrons among extensive drug resistance Acinetobacter baumanii strains isolated from intensive care units in Hamadan, west province, Iran. Iran J Med Microbiol. 2014;8(3):8-14.

31. Lin MF, Liou ML, Tu CC, Yeh HW, Lan CY. Molecular epidemiology of integron-associated antimicrobial gene cassettes in the clinical isolates of Acinetobacter baumannii from northern Taiwan. Ann Lab Med. 2013;33(4):242-7. doi: 10.3343/alm.2013.33.4.242. [PubMed: 23826559].

32. Koczura R, Przyszlakowska B, Mokracka J, Kaznowski A. Class 1 integrons and antibiotic resistance of clinical Acinetobacter calcoaceticus-baumannii complex in Poznan, Poland. Curr Microbiol. 2014;69(3):258-62. doi: 10.1007/s00284-014-0581-0. [PubMed: 24740302].

33. Bergogne-Berezin E, Towner KJ. Acinetobacter spp. as nosocomial pathogens: microbiological, clinical, and epidemiological features. Clin Microbiol Rev. 1996;9(2):148-65. [PubMed: 8964033]. 